infection with $\mathrm{X}$-irradiated motacercarise will influence the course of normal infection in mice and rabbits.

Parasitology Department,

$$
\text { D. L. HUGHES }
$$

Research Division,

Allen and Hanburys, Ltd.,

Ware, Hertfordshire.

IShiral, M., Sci. Rep. G. Inst. Infect. Dis. Tokyo Univ., 6, 511 (1927),

Taylur, E. L., and Parfitt, J. W., Trans. Amer. Micro. Soc., 76, 327 (1957).

3 Hughes, D. L., M.Sc thesis, University of London (1859).

- Dawes Ben, $J$, Helminth., R. T. Leiper Supp., 41 (1961).

'Lagrange, E., and Gutmann, A., Rivista di Parasitologia, 22, N2, 93 (1961).

- Villella, J. B., Gomberg, H. J., and Gould, S. E., Science, 134, 1073 (1961).

\section{Development of Transplantation Immu- nity in the Regionalized Lymph Node following Extirpation of the Original Regional Lymph Node}

Tre extirpation of the rogional lymph node doubles the survival-time of a cutaneous homograft on the ear of a rabbiti,2. If we perform an indirect colour lymphography before and after extirpation, we can observe a further nodo which is connocted to the lymphatic system within 2 weeks and which previously did not belong to this collecting area ${ }^{3}$.

We huvo tried to verify whether this regionalized node is a sourco of transplantation immunity. To this end, we made use of the fact that the cells of a regional nodo and a cutanoous graft against which the node was immunized, grafted on various sites of the same ear of a rabbit, produce a considerable cdema of the ear within $48 \mathrm{hr}$.

The experiments were carried out on Chinchilla rabbits weighing $1,800-1,900 \mathrm{gm}$. In the control group a $2 \mathrm{~cm} . \times 2 \mathrm{~cm}$. full thickness cutaneous homograft was transplanted on the ear of the rabbit. One week after rejection of the graft (it survived about 11 days) tho rogional lymph nodo was oxtirpated after indirect colour lymphography and transplanted on the ear of another rabbit. Over it a cutaneous graft was transplanted against which the nodo was immunized. $48 \mathrm{hr}$. later both ears were weighed. In the second group the regional lymph node was extirpated simultaneously with the cutaneous grafting. Again a week later, after rejection of the graft (it survived 25 days on the average), the regionalized lymph node was extirpated after indirect lymphography and together with the respective graft it was transferred to the ear of a further rabbit. In tho third group an experiment similar to that of the control group was performod, with the exception that we extirpated the preauricular node which, in this case, was not a regional one and therefore not immunized against the graft.

Table 1. CHDEMa OF THE EAK 48 HR. AFHEK TKANSPLANTATroN ON GRAYT AND LYMPil NODE CELES YMMUNized AQAINGT TIIS GRAFT Weight of ear (gm.) after $48 \mathrm{hr}$, legional node and graft Non-immunized node and uraf

Control side Influenced side

$\begin{array}{ll}15 \cdot 1 \pm 1 \cdot 5 & 32 \cdot 2 \pm 2 \cdot 7 \\ 15 \cdot 8 \pm 1 \cdot 4 & 30 \cdot 7 \pm 2 \cdot 5\end{array}$

Tho results aro summarized in Table 1. Aftor iransplantation of tho regional node and of the respective graft a considerablo nedema developed so that the weight of the ear doubled compared with that of the non-influenced ono. Similarly, aftor trans. plantation of the node regionalized following the extirpation of the original regional node and the transplantation of the respective graft, a considerable cedema occurred and the weight of the ear doubled again. If we, however, transforred the preauricular node which was not regionalized because the oriyinal retroauricular node was intact, no oedema occurred after transplantation of the respective graft.

This leads us to presume that the node which is connected to the lymphatic system after the extirpation of the original regional node becomes one of the sources of transplantation immunity.

$$
\text { J. VRUBEL }
$$

H. VRUBELOVA

Instituto for Clinical and Experimental Surgery, Prague.

$\checkmark$ Vrubel, J., paper delivered at Seventh Ann. Conf. Inst. Clin. and Exp. Surg. (May 1958).

${ }^{2}$ Stark, R. 13. Dwyer, E. M., and De Forest, M., Ann. N.Y. Acad. Sci., 87, 140 (1900).

${ }^{8}$ Vrubel. J., Fulia Biologica (in the press)

- Vrubel, J., and Vrubelová, H., Science (in the press).

\section{Coccolith Formation}

WITH the application of culture methods to the study of coccolithophorids, ovidenco is now accumulating ${ }^{1}$ in favour of the older hypothesis that coccoliths are formed inside the cell. This hypothesis has recently received further support from electron microseope investigations of other types of scalo-bearing Chrysophyceae ${ }^{2}$. So far, however, the process of coccolith formation does not appear to have been studied by exporimental means.

In young cultures of Coccolithus huxleyi (Lohm.) Kamptn., I have on numerous occasions observed one (Fig. 1) or two coccoliths in the cytoplasm betweon the two chromatophores. Their actual liberation has not been observed, but the following experiment suggests that the average time needed by the cell to produce a now coccolith may bo less than $1 \mathrm{hr}$. Cells were grown in a medium of sufficiently low calcium content $(0.01 \mathrm{gm}$. calcium/l.) to prevent coccolith formation entirely, and were afterwards transferred to sea-water and exposed to light. During the next fow hours, various stagos in the development of a coccolith cover could be observed. Single coccoliths were seen inside cells that were either still completely naked or carried one or more external coccoliths. After $6 \mathrm{hr}$, the majority of cells had produced 5-10 coccoliths.

By means of volumetric calcium analysis and simultanoous coccolith counts, it was found that the calcium content of one Coccolithus huxleyi is $5.5 \times 10^{-13} \mathrm{gm}$. calcium. Assuming a cell radius of $2 \cdot 5 \mu$, an organic carbon content of $0.1 \mathrm{gm}$. per c.c. of

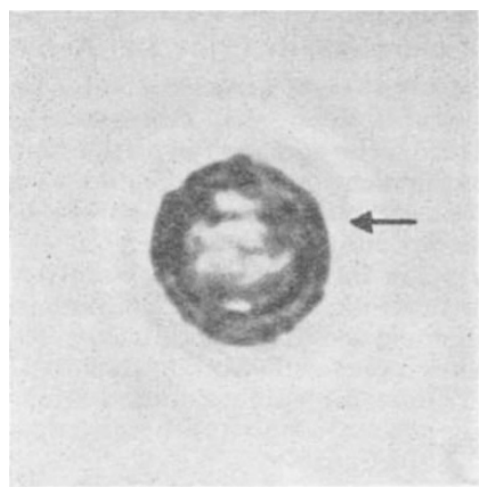

1.ig. 1. Coucolith (indieated by arrow) inside cell of Coccolithrs huxleyi (phase contrast, $x 4,000$ ) 